\title{
Thematic elements underlying risk perception amongst small and medium enterprise owner-managers
}

\begin{abstract}
Authors:
Udechukwu Ojiako ${ }^{1}$

Maxwell Chipulu ${ }^{1,2}$

Alasdair Marshall ${ }^{2}$

Poonam Baboolall ${ }^{2}$

\section{Affiliations:}

${ }^{1}$ Faculty of Management,

University of Johannesburg,

South Africa

${ }^{2}$ The Management School, University of Southampton, United Kingdom

\section{Correspondence to:}

Udechukwu Ojiako

Email:

uojiako@uj.ac.za

Postal address:

Faculty of Management,

University of Johannesburg,

Johannesburg 2006,

South Africa

Dates:

Received: 07 May 2013

Accepted: 07 June 2013

Published: 24 Feb. 2014

How to cite this article: Ojiako, U., Chipulu, M. Marshall, A. \& Baboolall, P., 2014, 'Thematic elements underlying risk perception amongst small and medium enterprise owner-managers' Acta Commercii 14(1), Art. \#199, 9 pages. http://dx.doi. org/10.4102/ac.v14i1.199
\end{abstract}

\section{Copyright:}

(C) 2014. The Authors.

Licensee: AOSIS

OpenJournals. This work

is licensed under the

Creative Commons

Attribution License.
Orientation: The article discusses the parameters that underlie the perception of risk amongst SME owner-managers.

Research purpose: This article draws on research suggesting that interactions between industry-sector (situational) differences and cognitive biases may often be decisive in moulding risk perceptions.

Motivation for the study: Literature suggests that one of the most significant challenges facing entrepreneurs is the development of a clear understanding of what it means to experience and conceptualise 'risk' within the context of business entrepreneurship.

Research design, approach and method: Utilising data obtained from a random sample of 446 SME owner-managers in the south-east of England, this study employs a combination of tests, including a non-parametric test, Chi-square test and Cramer's V statistics test, to derive a series of thematic propositions that contribute to our understanding of how these entrepreneurs perceive decision risk.

Main findings: Findings highlight the situational decision factors that influence SME ownermanagers to overemphasise possible negative outcomes, thus constraining the creative imagination upon which their entrepreneurship depends.

Practical/managerial implications: It is generally accepted that decisions that may be highly innovative are not necessarily risky, unless the entity concerned is innovating in order to survive and its innovations have strategic significance. Based on this, we posit that there is an urgent need for entrepreneurs to focus less on risk associated with innovation and more on comprehensive analysis of all risk and uncertainty present around business-critical decisions.

Contribution/value-add: This study contributes to growing research examining the relationship between SME risk and innovation, which is at present sparse.

\section{Introduction}

\section{Outline}

What interests us in this study are risk perceptions and their impact on the way small and medium enterprise (SME) owner-managers (henceforth 'entrepreneurs') evaluate decision risks. Sitkin and Weingart (1995:1575) define decision risk as a construct used to characterise alternatives confronting decision-makers. Risk perceptions on the other hand are regarded by Weber, Blais and Betz (2002) as subjective judgments individuals make relating to the severity and characteristics of specific risks. In the same light, Klos, Weber and Weber (2005:1779) define risk perception as 'the subjective feeling of riskiness associated with a specific action or choice alternative'. Because risk perceptions in business decision-making are primarily determined by three key factors, (1) the relative level of financial commitment, (2) variability in expected outcomes and (3) any potential losses that may result from the financial commitment (Forlani \& Mullins 2000; Sitkin \& Pablo 1992), we posit that risk perceptions of entrepreneurs have a considerable impact on enacting and sustaining entrepreneurial opportunities through innovation.

\section{Entrepreneurial risk and innovation}

One of the most significant challenges facing entrepreneurs is therefore the development of a clear understanding of what it means to experience and conceptualise 'risk' within the context of business entrepreneurship. According to one view, 'the entrepreneurship field is too broad [at this time] to effectively demand a single conceptualization of risk' (Janney \& Dess 2006:390). To scope the field, however, we can observe that risk is generally considered from three fundamentally varying perspectives: 'preparedness' (Brindley 2005), 'perception' (Klos et al. 2005; Weber et al. 2002; Weber \& Milliman 1997; Sitkin \& Weingart 1995) and 'propensity' (Brockhaus 1980). 
A further conceptualisation arising specifically from within an entrepreneurship perspective (see Forlani \& Mullins 2000; Ruhnka \& Young 1991) treats risk as uncertainty over potential loss associated with decisions relating to enacting and sustaining entrepreneurial opportunities. Within this context, risk may also be conceived as an 'event' that has economic value (Armour \& Teece 1978; Sitkin \& Pablo 1992). Taking this approach, the outcomes of events that have the greatest variability ${ }^{1}$ in terms of economic output and gain are likely to be perceived as more 'risky'. Here we seem to get closest to a conceptualisation of risk that reflects the phenomenology of the entrepreneurial situation. Crucially, the potential for both loss and gain here become salient influences that must be balanced or traded off against one another by the entrepreneurial mind (Forlani \& Mullins ibid.; Janney \& Dess 2006).

To the best of our knowledge, only a limited number of studies have sought to examine the relationship between risk and innovation (see a review by Marshall \& Ojiako 2010). According to Marshall and Ojiako, scholars have been faced with considerable challenges when examining the relationship between risk and innovation because of (1) the tradition of uncritically juxtaposing both concepts with management rhetoric and (2) the lazy co-application of both terms as descriptive properties when describing managerial activity that is 'novel'.

Although risk and innovation have traditionally been used as substitute terms for one another within that context, this rhetoric serves to obscure an important reality: levels of risk and innovation do not co-vary. Risk exposures may vary both with creative innovation and with the fortitude or dogged attachment that allows the status quo to persist. Unsurprisingly, then, thereisnoevidence of a directcorrelation between risk-taking behaviour and entrepreneurial success, (Colton \& Udell 1976). The notion that action considered risky may not necessarily be innovative begs the question of whether and to what extent this understanding accords with the conceptualisations of risk favored by entrepreneurs themselves. To explore this question, our article is structured as follows: following this introduction, section two explores relevant literature on entrepreneurship, risk and innovation; section three then explains the empirical study; in the fourth section, we conduct an analysis of the data collected and present our findings; we then discuss the findings in section five and draw conclusions in section six.

\section{Entrepreneurship, risk and innovation \\ Perceptions}

From a review of extant literature (Allen \& Webb 2011; Alvarez \& Barney 2005; Clercq \& Castañer 2011; Keh, Foo \& Lim 2002; Ruhnka \& Young 1991; Simon, Houghton \& Aquino 2000), there appears to be enough evidence to suggest an ever-growing interest amongst behavioural 1.The deviation between expected and actual event outcome. science and entrepreneurship scholars on the question of entrepreneurial risk and decision-making. What can be gathered from this literature is that there are two main areas of interest: the first is perceptions that deal with how sensory information is organised, identified and interpreted to support an understanding of the environment and wider society, whilst the second deals with cognitive attitudes that inform how individuals (entrepreneurs) arrive at decisions (Forlani \& Mullins 2000; Parker 2006; Smith, Gannon \& Grimm 1988). In sum, the literature (Forbes 1999; Gaglio \& Katz 2001; Hill \& Levenhagen 1995; Krueger 2007; Mitchell et al. 2007) informs us that not only will mental models influence how entrepreneurial risk is perceived (and therefore how decisions are made), but also that these models are impacted by various demographic variables (Byrnes, Miller \& Schafer 1999) and other 'external' factors such as culture (Chand \& Ghorbani 2011), ethnicity (Ibrahim \& Galt 2011; Ilhan-Nas, Sahin \& Cilingir 2011) and religion (Pearce, Fritz \& Davis 2010).

\section{Understanding how decision risks are framed and evaluated}

Scholars seeking to understand how risks are framed and evaluated, such as Wiseman and Gomez-Mejia (1998), emphasise the need to understand prospect theory (see Fiegenbaum \& Thomas 1988; Kahneman \& Tversky 1979). Prospect theory is a descriptive theory within behavioural economics which suggests that an individual's willingness to take risk is dependent on how the likely outcome is framed and evaluated against an attributed reference point. The theory contends that we think about possible losses and gains in very different ways. Most individuals are less likely to accept sure losses than they are to accept sure gains (Kahneman \& Tversky 1979). These stances have important implications for which levels of risk-taking are deemed acceptable. For example, literature (Holtgrave, Lawler \& Spann 1991; Odean 1998; Thaler \& Johnson 1990) suggests that in the face of loss we clutch at straws by imagining there to be to more and better 'opportunities' for redeeming or averting losses than truly exist. Sullivan (1993) however suggests that although managers are generally risk seeking when risks are framed from the perspective of loss, they tend to switch to a risk-averse stance when potential losses become ruinous in their magnitudes. In most circumstances, however, the general tendency is for entrepreneurs to take substantial risks when the alternative is a certain loss or if the payoff is unusually large (i.e. when the risks to be taken are justifiable with reference to the likely rewards) (see Bernardo \& Welch 2001). Within these justificatory thought processes around possible gain, large prizes with low probabilities are often more appealing to entrepreneurs than smaller prizes with higher probabilities. And so this delivers us the useful generalisation that the entrepreneurial mind is usually prepared to take big risks, both to achieve large gains and to avoid or recover from large but not catastrophic losses.

\section{Risk and perceptions}

Of course there are dangers associated with this sort of academic generalisation. Scholars have long been interested 
in how industry-sector (situational) differences and personal characteristics influence how entrepreneurs evaluate'decision risk'. This interest is driven by a need to accurately predict entrepreneurial behaviour, which cannot afford to neglect contextual factors. Academic studies need to take great care not to neglect such factors. Slovic et al. (1978) observe that experts frame risk within narrower sets of dimensions than non-experts. In particular, their statistical-probabilistic approaches seem to incline more to reductionism than can be said of lay perspectives, which are based more on elaborate idiographic sense-making narratives, and which are not easily stripped from the contexts within which they originate (see also Vaughan 1990). Malenka et al. (1993) also found that the framing of risk in relative versus absolute terms may have a major influence on an individual's decision preference. This leads us to consider that risk preferences may to some extent be path-dependent on the unique, individualised risk experiences of entrepreneurs, which lead them to anchor their forward-looking risk assessments on what their experience tells them about the likelihood or impact of risks they have already encountered (or indeed not encountered). Similarly, Weber, Ames and Blais (2005), Weber et al. (2002) and Klos et al. (2005) suggest that how individuals perceive risk is primarily dependent on how predisposed they are to emphasise specific dimensions of risk events. This once more leads us to reflect upon the importance of narrative sensemaking within specific entrepreneurial contexts.

Another parameter that has attracted the attention of scholars such as Shapira (1993), May (1995) and Helliar et al. (2002) concerns the influence of industry-sector (situational) differences on risk perceptions. The industry perspective is important because it gives managerial decisions meaning. Helliar et al. found differences in risk attitudes between accountants and other managers. Findings like this are unsurprising given that different organisational functions have different risk exposures. This means that they must meet different expectations regarding the cultural and psychological stances to be taken about these risk exposures. Clearly, most organisations that value risktaking creatives in their research or marketing departments may equally value risk-averse conservative managers in their finance and treasury departments. Risk 'tolerances' and 'appetites' can be expected to vary in this way, right across organisations. In addition to the importance of these often finely differentiated aspects of organisational context, scholars have also found individual traits to be important in the framing of risk perceptions. It will therefore appear that different organisational functions may attract people with certain traits, which suggests to us that influences of personality traits will often be bound up with the influence of organisational context in co-determining risk preferences. To expand on this slightly, both De Bruin, Parker and Fischhoff (2007) and Peters and Levin (2008) found that individual differences in general personality traits and characteristics such as age, gender and culture moderated differential reactions to potential gains and losses resulting from risk. This finding has been consistently supported by substantial research conducted in the field by Weber and her colleagues (see Weber et al. 2002; Weber \& Hsee 2000; Weber \& Milliman 1997). Taking stock of this research, we suggest that it is necessary to be extremely mindful of the dangers associated with misapplying psychological generalisations to specific entrepreneurial decision contexts.

\section{Development of the research questions}

Given the above diversity of relevant factors, it is perhaps unsurprising that academic efforts to understand the risk decisions of entrepreneurs (Behr \& Guttler 2007; Brockhaus 1980; Carland, Carland \& Pearce 1995; Janney \& Dess 2006) have so far been unable to develop predictive models for entrepreneurial risk decision-making. Yet the ability to be able to make such predictions is critical, not just to scholars, but for investors and venture capitalists seeking to ensure that appropriate resources are directed towards SMEs most likely to innovate (and, by implication, guarantee returns on investments). In addition, studying entrepreneurial risk evaluation should also be of interest to scholars because of the alarming rate of SME start-up failures, and reports that entrepreneurs remain largely dissatisfied with their economic performance (Simon et al. 2000; Townsend, Busenitz \& Arthurs 2010). If the decision to either start up a small business or release a new product or service to the market is seen to be risky, and risk perception has an influence on risk-taking behaviour, then an understanding of the thematic elements that underlie risk perception amongst entrepreneurs becomes of vital importance to academics and practitioners alike. If, as scholarship claims, cognitive biases influence our perception of events, then it is expected that such perceptions will influence decision risk. In effect, as Simon et al. (2000) claim, risk perceptions influence critically important entrepreneurial decisions, especially those that relate to business innovation and hinge upon the frames employed by the decision-makers.

Scholars such as Lumpkin and Dess (1996) have identified innovativeness and risk as behavioral dimensions of an entrepreneurial orientation, as we have already stated; however, very little extant literature within this emerging field has articulated the relationship between risk and innovation, especially within the context of entrepreneurship. Therefore, if SME decision-making is perceived as involving risk due to the ceaseless and perhaps intensifying demand for innovation, then it makes absolute sense to undertake a study designed to understand how entrepreneurs evaluate decision risk. A brief review of literature looking to set the agenda for entrepreneurship research (Kamm et al. 1990; Low \& MacMillan 1988; Shane \& Venkataraman 2000; Ucbasaran et al. 2001; Wiklund et al. 2011; Zahra et al. 2000; Zahra, Sapienza \& Davidsson 2006) appears to suggest that studies examining the relationship between SME risk and innovation are, at present, surprisingly sparse.

Therefore, framing our research question around the notion of 'what are the key issues?' (see Zahra 2007), we identify two research questions in this study: 
- What are the key elements that underlie risk perception amongst entrepreneurs?

- What risks do entrepreneurs regard as posing the greatest risk to their innovative capabilities?

\section{The study \\ Sampling and overview}

To address the research questions, data were gathered from a survey of members of the Federation of Small Businesses in Hampshire (FSB-H). All members of the FSB-H were contacted by email. The membership details of the federation were provided through the Small Enterprise Hub, a collaborative operated in partnership between the University of Southampton and the FSB-H. Due to reported low response problems with Web-based surveys (Mehta \& Sivadas 1995), a postal survey was employed. In total, 446 surveys were mailed out to FSB-H members in July 2010; 138 members (our 'entrepreneurs') responded to our survey. However, an examination of the returned questionnaires showed that a substantial number of respondents had not completed the survey $^{2}$. These questionnaires were discarded, leaving a total of 103 questionnaires available for analysis. The survey was divided into two parts: a general questionnaire survey and a probability scenario experiment.

\section{The general questionnaire}

The general questionnaire consisted of three sections. The first section gathered demographic data. In the second section, we sought to assess the risk perception of each of the respondents (thus addressing the first research question). In this section, a total of 13 questions were posed to the respondents. In the third section (which addresses the second research question), we sought to gain an understanding of what risks entrepreneurs regarded as posing the greatest threat (to their innovative capabilities). Here, a total of eight risk types were listed. The second and third parts of the questionnaire were developed largely from an earlier study by Helliar et al. (2002), which focused on examining risk attitudes of Scottish managers; that study is relevant to this one because it sought to understand the extent to which risks are evaluated, based on either simple biases or assessments of the magnitudes of outcomes. In the second section, the questions were built against a five-point Likert chart, ranging from 1 (strongly agree) to 5 (strongly disagree). For the questions in section 3 focusing on risk type, the respondents were asked to rank risks from 1 (extremely low) to 5 (extremely high)'.

\section{The probability scenario (risk perception in investments)}

To evoke a feeling of risk, and recognising that the risk 'focus' of entrepreneurs has traditionally been on the maximisation of investment decisions (see Carbo-Valverde, Rodriguez-Fernandez \& Udell 2008), we employed, in line with recommendations by Kunreuther, Novemsky and Kahneman (2001), the use of probability scenarios. The use of such scenarios is supported by studies (see Weber et al. returned the questionnaire with too many questions left unanswered.
2002), which argue that their use facilitates a more natural conceptualisation of how individuals construct their risk preferences from trade-offs between anticipated losses and gains.

We identified key investment decision contexts that related specifically to relationships between SME opportunities, risk and innovation, based on the existing literature (Verbees \& Meulenberg 2004; Vermeulen 2005). We provided five major scenarios with associated investment options framed against worse (probability of 1-p) or best outcome (probability $p$ ). Specifically, we developed our scenarios from two earlier studies: Keh et al. (2002) and Wang and Fischbeck (2008).

\section{Analysis of data and findings Data analysis}

We used SPSS 17.0 for data analysis, using descriptive statistics to present demographic data. In terms of understanding how individual characteristics such as age and gender impacted on risk perceptions, we used a combination of tests including a non-parametric test (specifically the Friedman test), Chisquare test and Cramer's V statistics test (Cramer 2003). We also employed cross-tabulation and correlations to examine the relationship between factors such as gender, income level and years of work experience.

\section{Demography}

A brief demographic overview of the respondents showed the following: of the total responses used in the final analysis, 72 were male, whilst 31 were female. Age distribution is as follows: $4.9 \%$ were $18-30$ years old, $16.5 \%$ were $31-40$ years old, $32 \%$ were $41-50$ years old, $37.9 \%$ were $51-60$ years old and $8.7 \%$ were older than 60 .

\section{Risk propensity (from questionnaire)}

We began our analysis with a hypothesis that explicitly recognised the criticality of loss and gain framing (as highlighted by prospect theory) as a determinant of risk perception:

$\mathbf{H}_{0}$ : Decision risks are evaluated by SME owner-managers from a loss perspective.

$\mathbf{H}_{1}$ : Decision risks are evaluated by SME owner-managers from a gain perspective.

Inference statistics were used to test what factors had an effect on risk perception. As a general rule, we set the level of significance at $0.05(\alpha=0.05)$; therefore, if the results from SPSS indicated that Asymp.Sig was less than the determined $\alpha$, our procedure was to reject null hypothesis $\mathrm{H}_{0}$ and accept alternative hypothesis $\mathrm{H}_{1}$.

We employed the Npar and Friedman tests, finding that Asymp.Sig $=0.000, \leq \alpha$; therefore, we rejected $\mathrm{H}_{1}$. Based on this finding, we put forward the first proposition:

- PR1: Decision risks are primarily evaluated by SME owner-managers from a loss perspective. 


\section{Risk perception in investments (from the probability scenario)}

As earlier mentioned during the review of the literature, risk may be perceived as an event that has economic value. We therefore set out to use the probability scenario to examine risk perceptions based on (1) decisions involving risk choices between three investment options, (2) investment decisions relating to four innovative initiatives and (3) risk perceptions under conditions of insolvency.

In the first scenario, we set out to examine how entrepreneurs perceived risk when making decisions involving risk choices between three investment options. In this experiment, the respondents were asked, 'If you had three investment choices, are you more likely to choose an investment (1) with the lowest risk, but least profitable, (2) with highest risk, but most profitable, or (3) with an intermediate or average alternative?' Here, we found that more managers (72\%) chose the intermediate alternative rather than the two extreme categories of risk choices, thus reiterating earlier highlighted studies by Brockhaus (1980, 1982), which suggested that, similar to managers in large firms, entrepreneurs exhibited a preference for decisions with moderate risk.

Interestingly, cross-tabulation showed that none of the female respondents chose the riskier innovation option. For the second scenario, we asked respondents to make an investment decision relating to four initiatives. The first and second initiatives (A and B) were regarded as having low risk, but were associated with a low payoff. The third (C) and fourth (D) investment options were associated with high risk and high payoffs. A and $C$ will be closely monitored whilst B and D will not. Respondents were asked choose which form of investment option they would select from the combinations 'A and $\mathrm{C}^{\prime}$, 'B and $\mathrm{C}^{\prime}$, 'A and $\mathrm{D}$ ' or 'B and $\mathrm{D}$ '. In this scenario, our objective was to gain an understanding of perceptions of risk amongst entrepreneurs when making decisions involving choices between monitored and nonmonitored investments. This question related to earlier work we cited discussing the relationship between entrepreneurial investments, resource allocation (cost of monitoring) and SME innovation. An analysis of the responses (Table 1) showed that most respondents chose initiative A (low risk, low payoffs) and C (high risk, high payoffs), thus leading us to propose that:

- PR2: SME owner-managers' perception of risk is balanced by an emphasis on monitoring and control.

The results perhaps reiterate earlier studies (see Slovic et al. 2004), which emphasise the role cognitive constructs play in the perception of risk. The results therefore seem to have a critical implication for entrepreneurs, especially when one considers the relationship between risk and innovation. Cognition of risk may consider the riskiness of an event, system or process. It may refer to any innovation involved. Although risky innovations are expected to drive change or transformation, it is pertinent to understand that SME innovation is often primarily dependent on the individual risk preferences of individual owner-managers. The reality is that individual owner-managers will exhibit differences in terms of their individual perceptions of risk. As we have mentioned in our earlier discussion, the problems to be overcome through the use of such devices can include both 'clutching at straws' by overestimating opportunities, and extreme risk aversion when economic survival is in jeopardy. An essential starting point in the creation of such devices is the identification of common postures towards risk that can lead to poor decision-making. Following this logic, it makes sense to value the findings in Table 1 as very tentative generalisations that help us to map the entrepreneurial mind's handling of risk and innovation.

In the third scenario, we focused on how risk framed in terms of gains and losses influenced decision-making of entrepreneurs. In this scenario, the respondents were asked to choose between two options:

The turnover of your company is expected to be $£ 20$ million. Owing to difficult economic conditions, your company is facing an expected cash loss of $£ 600000$ for the next quarter. You are considering investing in two technology ventures as a means of turning the situation around. The first venture would result in a certain saving of $£ 200000$. For the second venture, you estimate that there is a one-third probability of saving the entire $£ 600000$ and a two-thirds probability of saving nothing.

\section{Findings from the third scenario}

We commenced our analysis of the findings from the third scenario by calculating the expected monetary outcome (EMV) for the scenarios (see Table 2) using the equation:

$\mathrm{EMV}=\sum_{n-1}^{N}$ Value $_{n} \mathrm{X}$ Probability ${ }_{n}$

We then set out to examine how risk was perceived when framed in terms of gains (Table 3 ).

The outcome of our EMV analysis, shown in Table 3, led us to propose:

- PR3: When decision risks are framed in terms of gains, SME owner-managers are more likely to minimise risk.

Using the same scenario, we set out to gain an understanding of how entrepreneurs framed risk, this time when options are in terms of losses (Table 4).

TABLE 1: Frequency and monitoring: Which pair of initiatives would you choose?

\begin{tabular}{lcccc}
\hline Initiatives & Frequency & $\mathbf{\%}$ & Valid \% & Cumulative \% \\
\hline A and C & 91 & 88.3 & 88.3 & 88.3 \\
B and C & 3 & 2.9 & 2.9 & 91.3 \\
A and D & 5 & 4.9 & 4.9 & 96.1 \\
B and D & 4 & 3.9 & 3.9 & 100.0 \\
\hline Total & 103 & 100.00 & 100.00 & \\
\hline
\end{tabular}

TABLE 2: EMV for Initiative A, when options are in terms of gains.

\begin{tabular}{lll}
\hline Option & Calculation & EMV (f) \\
\hline Option 1 & Nil & 200000 \\
Option 2 & $(1 / 3 \times 600)+(2 / 3 \times 0)$ & 20000 \\
\hline
\end{tabular}

EMV; expected monetary outcome. 
TABLE 3: EMV when options are in terms of gains or frequencies.

\begin{tabular}{llll}
\hline Options & Frequency & $\%$ & Cumulative $\%$ \\
\hline Save $f 200000$ with certainty & 77 & 74.8 & 74.8 \\
One-third probability of saving $£ 600000$ and two-third probability of saving nothing & 26 & 25.2 & 25.2 \\
\hline Total & 103 & 100 & 100 \\
\hline
\end{tabular}

\section{Total}

103

EMV; expected monetary outcome.

TABLE 4: EMV for Initiative A, when options are in terms of losses.

\begin{tabular}{lll}
\hline Option & Calculation & EMV (f) \\
\hline Option 1 & Nil & 400000 \\
Option 2 & $(1 / 3 \times 0)+(2 / 3 \times 600)$ & 400000 \\
\hline
\end{tabular}

EMV; expected monetary outcome.

Participants were presented with the same decision situation, except that the option given to them was either to lose $£ 400$ 000 for certain or take the more risky option where there was a two-thirds probability of losing the full $£ 600000$. Based on the analysis of the EMV calculations (Table 4), we propose that:

- PR4: When decisions risks are framed in terms of losses, SME owner-managers are more likely to maximise risk.

In the final scenario, we explored risk perceptions under conditions of insolvency. Existing research (see Freel 2000; Frormann 2006; Gladstone \& Lee 1995) that has explored insolvency systems in the UK and their impact on entrepreneurs suggests that although ostensible attempts had been made by the government to reform insolvency law, the current legal framework surrounding SME insolvency, especially as relates to its severity, has serious negative ramifications for SME innovation, especially due to the fact that it discourages entrepreneurs from re-entering the market.

The respondents were presented with a scenario about investing in Project Z. Respondents were informed that there was a $10 \%$ chance that the firm will make $£ 6$ million if things go favourably, but there is a $90 \%$ chance that the project will fail and the firm will record a loss of $£ 12$ million as a result. The respondents were then asked whether they would (1) invest in Project Z, with a 10\% chance of making $£ 6$ million and a $90 \%$ chance of losing $£ 12$ million, or (2) do nothing, at a loss of $£ 3$ million. The assumption in this scenario was that investing in Project $Z$ was the riskier option because of a higher chance of insolvency. Overall, we found that a majority ( $84 \%)$ of respondents opted for the least risky option, which was to do nothing and suffer a loss of $£ 300000$. We then put forward our fifth proposal:

- PR5: In situations where the magnitude and probability of future losses occurring were considered to have catastrophic consequences, SME owner-managers were likely to be risk averse.

\section{Discussion (and implications for innovation)}

Literature on innovation (Cooper 2011; Siguaw, Simpson \& Enz 2006; Verganti 2008) appears on close examination to continue to suggest a tendency for the existence of a 'conservative' outlook, in effect a suggestion that firms (including SMEs) are not naturally oriented to innovate, and that the desire to innovate is only driven by a need to react to perceived threats (equating to 'risks' in the minds of entrepreneurs). In fact, as Miller and Friesen (1982:3) earlier alluded, 'innovation is performed infrequently, and, perhaps, because of its disruptive nature, reluctantly'. This model, according to Miller and Friesen, puts forward four major drivers for firm innovation: (1) environmental challenges, (2) information in the form of intelligence on the challenges, (3) an ability and competency willingness to innovate and (4) existence of appropriate decision-making frameworks.

The findings from the present study appear to agree with earlier studies (see Peters \& Levin 2008; Sitkin \& Weingart 1995; Slovic et al. 2004; Weber et al. 2002; Weber \& Milliman 1997), which emphasise the influence of both individual and situational (context) factors influencing how individuals perceive risk and analyse alternative decision options. In our study, we found that the decision risk perceptions of entrepreneurs appear predominantly to be a function of considerations of loss, and not of gains, that may result from a decision. Our finding is not particularly surprising, for although entrepreneurs were for a long time in scholarship assumed to have a higher propensity for risk, some scholars such as Xu and Ruef (2004) have shown that in a bid to deal with the high risk of business failure, entrepreneurs were actually more risk averse than non-entrepreneurs. In our view, this very plausible possibility raises considerable questions about how innovation propensity, considered as a critical aspect of entrepreneurial activity, can and should be nurtured.

A critical review of entrepreneurship literature shows that the lazy juxtaposition of 'risk' and 'innovation' is a regular occurrence. Arguably, this can produce an unhelpful mental association within the entrepreneurial mind. Although to some scholars (Baregheh, Rowley \& Sambrook 2009; Ben-Ari \& Or-Chen 2009; Dewett 2004) there may be a good reason for this link, explained for example from the perspective that risk is an inevitable accompaniment to all innovation, Marshall and Ojiako (2010) warn that we need to uncouple the two concepts by recognising that risks intensify and diminish no matter whether and to what extent entrepreneurs decide to innovate. We accept Marshall and Ojiako's argument based on the idea that many risks are actually just 'Knightian uncertainties' (Knight 1921) with respect to possible future outcomes. Innovation on the other hand, implies sequences of creative imagination and endeavour (Amabile 1996). Hence, the two concepts are very different indeed. However, because innovation involves an element of transformation with uncertain consequences (Tushman \& Anderson 2004), there are necessarily 'risks' (i.e. Knightian 
uncertainties) involved. Furthermore, a product or service may well be highly innovative, but it can be of low risk from an investment or value perspective, especially where the entity can easily afford to absorb the losses that might result from failed innovation, and indeed where it is not reliant on the profits to be made from successful innovation. By the same token, this of course implies that decisions that may be highly innovative are not necessarily risky - unless the entity concerned is innovating in order to survive and its innovations have strategic significance. Taking this approach, what seems to be the determining factor in SME risk and innovation discourse is the question of uncertainty or, more appropriately, the reduction of all uncertainties that matter, specifically for business-critical decisions.

We therefore posit that perhaps there is a more urgent need for entrepreneurs to focus less on risk associated with innovation (as is encouraged by the lazy entanglement of the two terms within business discourse) and more on the need for a comprehensive analysis of all risk and uncertainty present around business-critical decisions. Diligent attention to risks associated with innovation always needs to be 'balanced' against diligent attention to risks associated with the persistence of the status quo. It seems reasonable to conclude that only in this way can both the biases described by prospect theory and the conservative fear of strategic innovation be tackled systematically within entrepreneurial decision processes. This change in emphasis has serious implications for entrepreneurs. Thinking beyond the risks that necessarily accompany innovation, entrepreneurs must be willing to take decisions within what they must recognise to be a much broader realm of uncertainty. As De Jong (2011) reminds us, and as Marshall and Ojiako (2010) emphasise strongly, the innovation process is surrounded by risk and uncertainty. These things attach to the persistence of the status quo, and innovation merely changes the forms and extents they take. Even inaction cannot freeze the entity's exposure to risk and uncertainty, as these are always transforming within the entity's environment no matter whether the entity acts or not. Inevitably, entrepreneurs will feel pressure to reduce uncertainty through framing, for practical decisionmaking purposes, by focusing either on risks produced by innovation, or on risks associated with standing still. The use of 'balanced' decision processes seems to be a sensible corrective to this narrowing of scope. Evidence suggests that entrepreneurs have the capacity to tolerate the broad realm of risk and uncertainty that must be acknowledged within such processes.

We recognise from extant literature that entrepreneurs generally have a higher propensity than other managers to take decisions involving risk. Scholarship already proposes that managers with a higher propensity to risk are more able to deal with the ambiguity of innovation. Yet of course this same evidence highlights biases that must be overcome. In our study, although we certainly found such behaviour (leading to propositions PR3, PR4, PR5 and PR6), there were further issues that arose, especially in relation to the first two propositions. In terms of the first proposition (PR1), we found that entrepreneurs contextualised risk primarily from a loss perspective. Certainly, such a position makes entrepreneurs less willing to accept the ambiguities associated with innovation. In terms of the second proposition (PR2), we found that entrepreneurs' propensity for risk appeared balanced by an emphasis on monitoring and control. This finding might partly be explained by our fifth proposition (PR5): in situations where the magnitude and probability of future losses occurring were considered to have catastrophic consequences, entrepreneurs were likely not to be risk seeking. Although the significance of this has of course increased along with global economic downturn, our finding is opposite to earlier findings by, for example, Dewett (2004), who found evidence to suggest risk-seeking behaviour when dealing with business decisions that held significant threats to business survival. To some extent this could be construed as a manifestation of prospect theory, yet it also makes sense to view it as an emerging equation, in the entrepreneurial mind, between innovation and adapt-or-die necessity.

\section{Conclusion}

In this study, we examined risk perceptions and their impact on the ways in which entrepreneurs evaluate decision risks. Our study approach is particularly appropriate due to (1) a lack of consensus on the relative risk-taking propensities of entrepreneurs and managers that has produced conflicting findings (see Stewart \& Roth 2001) and (2) an interest in the use of psychometric testing in ascertaining the existence of 'risk innovators' competencies amongst entrepreneurs (Caird 1993; Shaver \& Scott 1991). This study serves as a means of acquiring an understanding of whether entrepreneurs are able to demonstrate competencies representative of 'risk innovators'. There are opportunities for further studies in this area, one such opportunity being to examine the relationship between entrepreneurial risk and innovation from the perspective of decision consequences (especially where firm survival is explicitly placed at issue). As expected, the study was not without limitations. In the first place, the overall sample size is limited in as much as it was drawn from the County of Hampshire in England, an area generally recognised as a hub of the UK's 'knowledge economy' (Hampshire County Council 2011:iii). Therefore, one could argue that the sample is not overall representative of UK entrepreneurship. Secondly, although the results that emerged from the analysis of data are correlational, no robust exploration of the causal constructs that might exist between risk perception and risk-taking behaviour was undertaken. According to Klos et al. (2005), and Weber and Milliman (1997), these constructs (or personality variables), may have considerable impact on risk perception, and therefore warrant further attention by scholars.

\section{Acknowledgements Competing interests}

The authors declare that they have no financial or personal relationship(s) that may have inappropriately influenced them in writing this article. 


\section{Authors' contributions}

U.O. (University of Johannesburg), M.C. (University of Southampton and University of Johannesburg), A.M. (University of Southampton), and P.B. (University of Southampton) all made equal conceptual contributions that led to the development of this article.

\section{References}

Allen, J. \& Webb, J., 2011, 'Behavioural orientations of non-profit boards as a factor in entrepreneurial performance: Does governance matter?', Journal of Management Studies 48(4), 829-856. http://dx.doi.org/10.1111/j.1467-6486.2010.00956.x

Alvarez, S. \& Barney, J., 2005, 'How do entrepreneurs organize firms under conditions of uncertainty?', Journal of Management 31(5), 776-793. http://dx.doi. org/10.1177/0149206305279486

Amabile, T., 1996, Creativity in Context, Westview Press, Boulder, CO.

Armour, H. \& Teece, D., 1978, 'Organization structure and economic performance: A test of multidivisional hypotheses', Bell Journal of Economics 9, 106-122. http:// dx.doi.org/10.2307/3003615

Baregheh, A., Rowley J. \& Sambrook, S., 2009, 'Towards a multidisciplinary definition of innovation', Management Decision 47(8), 1323-1339. http://dx.doi. org $/ 10.1108 / 00251740910984578$

Behr, P. \& Guttler, A., 2007, 'Credit risk assessment and relationship lending: An empirical analysis of German small and medium-sized enterprises', Journal of Small Business Management 45(2), 194-213.

Ben-Ari, A. \& Or-Chen, K., 2009, 'Integrating competing conceptions of risk: A call for future direction of research', Journal of Risk Research 12(6), 865-877. http:// dx.doi.org/10.1080/13669870902899674

Bernardo, A. \& Welch, I., 2001, 'On the evolution of overconfidence and entrepreneurs', Journal of Economics and Management Strategy 10, 301-330. http://dx.doi.org/10.1162/105864001316907964

Brindley, C., 2005, 'Barriers to women achieving their entrepreneurial potential: Women and risk', International Journal of Entrepreneurial Behaviour \& Research 11(2), 144-161. http://dx.doi.org/10.1108/13552550510590554

Brockhaus, R., 1980, 'Risk taking propensity of entrepreneurs', Academy of Management Journal 23(3), 509-520. http://dx.doi.org/10.2307/255515

Brockhaus, R., 1982, 'The psychology of the entrepreneur', in C. Kent, D. Sexton \& K. Vesper (eds.), The Encyclopedia of Entrepreneurship, pp. 39-57, Prentice Hall, Englewood Cliffs, NJ.

Byrnes, J., Miller, D. \& Schafer, W., 1999, 'Gender differences in risk taking: A metaanalysis', Psychological Bulletin 125(3), 367-383. http://dx.doi.org/10.1037/00332909.125.3.367

Caird, S., 1993, 'What do psychological tests suggest about entrepreneurs?', Journal of Managerial Psychology 8(6), 11-20. http://dx.doi. org/10.1108/02683949310047428

Carbo-Valverde, S., Rodriguez-Fernandez, F. \& Udell, G., 2008, Bank lending, financing constraints and SME investment, mimeo, viewed 02 February 2011, from http://www.eu-financial-system.org/fileadmin/content/Dokumente_Events/ Prague_2008_11th_conference/Carbo-Valverde.pdf

Carland, J., Carland, J. \& Pearce, J., 1995, 'Risk-taking propensity among entrepreneurs, small business owners, and managers', Journal of Business and Entrepreneurship 71, 15-23.

Chand, M. \& Ghorbani, M., 2011, 'National culture, networks and ethnic entrepreneurship: A comparison of the Indian and Chinese immigrants in the entrepreneurship: A comparison of the Indian and Chinese immigrants in the
US', International Business Review 20(6), 593-606. http://dx.doi.org/10.1016/j. ibusrev.2011.02.009

Clercq, D. \& Castañer, X., 2011, 'Entrepreneurial initiative selling within organizations: Towards a more comprehensive motivational framework', Journal of Management Studies 48(6), 1269-1290. http://dx.doi.org/10.1111/j.1467-6486.2010.00999.x

Colton, R. \& Udell, G., 1976, 'The national science foundation's innovation center: An experiment in training potential entrepreneurs and innovators', Journal of Small Business Management 21(3), 11-20.

Cooper, R., 2011, 'Perspective: The innovation dilemma: How to Innovate when the market is mature', Journal of Product Innovation Management 28(1), 2-27. http:// dx.doi.org/10.1111/j.1540-5885.2011.00858.x

Cramer, D., 2003, Advanced Quantitative Data Analysis, Open University Press, Maidenhead.

De Bruin, W., Parker, A. \& Fischhoff, B., 2007, 'Individual differences in adult decisionmaking competence', Journal of Personality and Social Psychology 92(5), 938956. http://dx.doi.org/10.1037/0022-3514.92.5.938, PMid:17484614

De Jong, J., 2011, The decision to exploit opportunities for innovation: A study of high-tech small-business owners, entrepreneurship theory and practice, viewed 01 June 2011, from http://onlinelibrary.wiley.com/doi/10.1111/j.15406520.2011.00459.x/full

Dewett, T., 2004, 'Creativity and strategic management: Individual and group considerations concerning decision alternatives in the top management teams', Journal of Managerial Psychology 19(2), 156-169. http://dx.doi. org/10.1108/02683940410526118

Fiegenbaum, A. \& Thomas, H., 1988, 'Attitudes toward risk and the risk-return paradox: Prospect theory explanations', Academy of Management Journal 31(1), 85-106. http://dx.doi.org/10.2307/256499
Forbes, D., 1999, 'Cognitive approaches to new venture creation', International Journal of Management Reviews 1(4), 415-439. http://dx.doi.org/10.1111/14682370.00021

Forlani, D. \& Mullins, J., 2000, 'Perceived risks and choices in entrepreneurs' new venture decisions', Journal of Business Venturing 15(4), 305-322. http://dx.doi. org/10.1016/S0883-9026(98)00017-2

Freel, M., 2000, 'Barriers to product innovation in small manufacturing firms', International Small Business Journal 18(2), 60-80. http://dx.doi. org/10.1177/0266242600182003

Frormann, D., 2006, 'Medium-sized business in Germany', International Journal of Entrepreneurship and Innovation Management 6(1-2), 18-26. http://dx.doi. org/10.1504/IJEIM.2006.008203

Gaglio, C. \& Katz, J., 2001, 'The psychological basis of opportunity identification: Entrepreneurial alertness', Small Business Economics 16(2), 95-111. http://dx.doi. org/10.1023/A:1011132102464

Gladstone, B. \& Lee, J., 1995, 'The operation of the insolvency system in the U.K. Some implications for entrepreneurialism', Small Business Economics 7(1), 55-66. http://dx.doi.org/10.1007/BF01074316

Hampshire County Council., 2011, Hampshire Economic Assessment: Executive Summary, viewed 02 April 2012, from http://www3.hants.gov.uk/hea_executive summary_2011.pdf

Helliar, C., Lonie, A., Power, D. \& Sinclair, C., 2002, 'Managerial attitudes to risk: A comparison of Scottish chartered accountants and U.K. managers', Journal of International Accounting, Auditing and Taxation 11(2), 165-190. http://dx.doi. org/10.1016/S1061-9518(02)00068-X

Hill, R. \& Levenhagen, M., 1995, 'Metaphors and mental models: Sensemaking and sensegiving in innovative and entrepreneurial activities', Journal of Management 21(6), 1057-1074. http://dx.doi.org/10.1177/014920639502100603

Holtgrave, D., Lawler, F. \& Spann, S., 1991, 'Physicians' risk attitudes, laboratory usage, and referral decisions: The case of an academic family practice center', Medical Decision Making 11, 125-130. http://dx.doi.org/10.1177/0272989X9101100210, PMid:1865781

Ibrahim, G. \& Galt, V., 2011, 'Explaining ethnic entrepreneurship: An evolutionary economics approach', International Business Review 20(6), 607-613. http:// dx.doi.org/10.1016/j.ibusrev.2011.02.010

Ilhan-Nas, T., Sahin, K. \& Cilingir, Z., 2011, 'International ethnic entrepreneurship: Antecedents, outcomes and environmental context', International Business Review 20(6), 614-626. http://dx.doi.org/10.1016/j.ibusrev.2011.02.011

Janney, J. \& Dess, G., 2006, 'The risk concept for entrepreneurs reconsidered: New challenges to the conventional wisdom', Journal of Business Venturing 21(3), 385400. http://dx.doi.org/10.1016/j.jbusvent.2005.06.003

Kahneman, D. \& Tversky, A., 1979, 'Prospect theory: An analysis of decision under risk', Econometrica 47(2), 263-329.

Kamm, J., Shuman, J., Seeger, J. \& Nurick, A., 1990, 'Entrepreneurial teams in new venture creation: A research agenda', Entrepreneurship Theory and Practice 14, 7-17.

Keh, H., Foo, M. \& Lim, B., 2002, 'Opportunity evaluation under risky conditions: The cognitive processes of entrepreneurs', Entrepreneurship Theory and Practice cognitive processes of entrepreneurs', Entrepreneurship Thed
27(2), 125-148. http://dx.doi.org/10.1111/1540-8520.00003

Klos, A., Weber, E.U. \& Weber, M., 2005, 'Risk perception and risk behaviour in repeated gambles', Management Science 51, 1777-1790. http://dx.doi. org $/ 10.1287 /$ mnsc.1050.0429

Knight, F., 1921, Risk, Uncertainty and Profit, Houghton Mifflin Company, Boston \& New York. PMid:17864564 PMCid:PMC1399809

Krueger, N., 2007, 'What lies beneath? The experiential essence of entrepreneurial thinking', Entrepreneurship Theory and Practice 31(1), 123-138. http://dx.doi. org/10.1111/j.1540-6520.2007.00166.x

Kunreuther, H., Novemsky, N. \& Kahneman, D., 2001, 'Making low probabilities useful', Journal of Risk and Uncertainty 23(2), 103-120. http://dx.doi. org/10.1023/A:1011111601406

Low, M. \& MacMillan, I., 1988, 'Entrepreneurship: Past research and future challenges', Journal of Management 14(2), 139-161. http://dx.doi. org/10.1177/014920638801400202

Lumpkin, G. \& Dess, G., 2001, 'Linking Two dimensions of entrepreneurial orientation to firm performance: The moderating role of environment and industry life cycle', Journal of Business Venturing 16(5), 429-451. http://dx.doi.org/10.1016/S08839026(00)00048-3

Malenka, D., Baron, J., Johansen, S., Wahrenberger, J. \& Ross, J., 1993, 'The framing effect of relative and absolute risk', Journal of General Internal Medicine 8(10), 543-548. http://dx.doi.org/10.1007/BF02599636, PMid:8271086

Marshall, A. \& Ojiako, G.U., 2010, 'From the myth of Prometheus to strategic resilience: Two cognitive paradigms linking risk and innovation', Prometheus 28(4), 343-360. $\mathrm{http}: / / \mathrm{dx}$.doi.org/10.1080/08109028.2010.539018

May, D., 1995, 'Do managerial motives influence firm risk reduction strategies?', Journal of Finance 4, 1291-1308. http://dx.doi.org/10.1111/j.1540-6261.1995. tb04059.x

Mehta, R. \& Sivadas, E., 1995, 'Comparing response rates and response content in mail versus electronic mail surveys', Journal of the Market Research Society 17,
$429-440$.

Miller, D. \& Friesen, P.H., 1982, 'Innovation in conservative and entrepreneurial firms: Two models of strategic momentum', Strategic Management Journal 3(1), 1-25. http://dx.doi.org/10.1002/smj.4250030102 
Mitchell, R., Busenitz, L., Bird, B., McMullen, J., Morse, E. \& Smith, J., 2007, 'The central question in entrepreneurial cognition research', Entrepreneurship Theory and Practice 31(1), 1-27. http://dx.doi.org/10.1111/j.1540-6520.2007.00161.x

Odean, T., 1998, 'Are investors reluctant to realise their losses', Journal of Finance 53, 1775-1798. http://dx.doi.org/10.1111/0022-1082.00072

Parker, S., 2006, 'Learning about the unknown: How fast do entrepreneurs adjust their beliefs?', Journal of Business Venturing 21(1), 1-26. http://dx.doi.org/10.1016/j. jbusvent.2004.07.005

Pearce, J., Fritz, D. \& Davis, P., 'Entrepreneurial orientation and the performance of religious congregations as predicted by rational choice theory', Entrepreneurship Theory and Practice 34(1), 219-248. http://dx.doi.org/10.1111/j.15406520.2009.00315.x

Peters, E. \& Levin, I., 2008, 'Dissecting the risky-choice framing effect: Numeracy as an individual-difference factor in weighting risky and riskless options', Judgment and Decision Making 3(6), 435-448.

Ruhnka, J. \& Young, J., 1991, 'Some hypotheses about risk in venture capital investing', Journal of Business Venturing 6(2), 115-133. http://dx.doi.org/10.1016/0883 9026(91)90014-5

Shane, S. \& Venkataraman, S., 2000, 'The promise of entrepreneurship as a field of research', Academy of Management Review 25(1), 217-226.

Shapira, Z., 1993, 'Ambiguity and risk-taking in organisations', Journal of Risk and Uncertainty 71, 89-94. http://dx.doi.org/10.1007/BF01065316

Shaver, K. \& Scott, L., 1991, 'Person, process, choice: The psychology of new venture creation', Entrepreneurship Theory and Practice 16(2), 23-45.

Siguaw, J., Simpson, P. \& Enz, C., 2006, 'Conceptualizing innovation orientation: A framework for study and integration of innovation research', Journal of Product Innovation Management 23(6), 556-574. http://dx.doi.org/10.1111/j.15405885.2006.00224.x

Simon, M., Houghton, S. \& Aquino, K., 2000, 'Cognitive biases, risk perception, and venture formation: How individuals decide to start companies', Journal of Busines Venturing 15(2), 113-134. http://dx.doi.org/10.1016/S0883-9026(98)00003-2

Sitkin, S. \& Pablo, A., 1992, 'Reconceptualising the determinants of risk behaviour', Academy of Management Review 17(1), 9-38.

Sitkin, S. \& Weingart, S., 1995, 'Determinants of risky decision-making behaviour: A test of the mediating role of risk perceptions and propensity', Academy of Management Journal 38(6), 1573-1592. http://dx.doi.org/10.2307/256844

Slovic, O., Fischhoff, B., Lichtenstein, S., Read, S. \& Combs, B., 1978, 'How safe is safe enough? A psychometric study of attitudes towards technological risk and benefits', Policy Sciences 9, 127-152. http://dx.doi.org/10.1007/BF00143739

Slovic, P., Finucane, M., Peters, E. \& Macgregor, D., 2004, 'Risk as analysis and risk as feelings: Some thoughts about affect, reason, risk and rationality', Risk Analysis 24(2), 1-12.

Smith, K., Gannon, M. \& Grimm, C., 1988, 'Decision making behaviour in smaller entrepreneurial and larger professionally managed firms' Journal of Business Venturing 3(3), 223-232.

Stewart, W. \& Roth, P., 2001, 'Risk propensity differences between entrepreneurs and managers: A meta-analytic review', Journal of Applied Psychology 86(1), 145-153. $\mathrm{http} / / / \mathrm{dx}$.doi.org/10.1037/0021-9010.86.1.145, PMid:11302226

Sullivan, K., 1993, 'An investigation of risk behaviour in financial decision-making', unpublished PhD dissertation, University of Massachusetts, Amherst.
Thaler, R. \& Johnson, E., 1990, 'Gambling with the house money and trying to break even: The effects of prior outcomes on risky choice', Management Science 36(6), 643-660. http://dx.doi.org/10.1287/mnsc.36.6.643

Townsend, D., Busenitz, L. \& Arthurs, J., 2010, 'To start or not to start: Outcome and ability expectations in the decision to start a new venture', Journal of Business Venturing 25(2), 192-202. http://dx.doi.org/10.1016/j.jbusvent.2008.05.003

Tushman, M. \& Anderson, P., 2004, Managing Strategic Innovation and Change, Oxford University Press, New York. PMid:15077368

Ucbasaran, D., Westhead, P. \& Wright, M., 2001, 'The focus of entrepreneurial research: Context, process and issues', Entrepreneurship Theory and Practice 25(4), 57-80.

Vaughan, E., 1990, Some factors influencing the nonexpert's perception and evaluation of environmental risks, Garland Publishing, New York.

Verbees, J. \& Meulenberg, M., 2004, 'Market orientation, innovativeness, product innovation, and performance in small firms', Journal of Small Business Management 42(2), 134-154. http://dx.doi.org/10.1111/j.1540-627X.2004.00102.x

Verganti, R., 2008, 'Design, meanings, and radical innovation: A meta-model and a research agenda', Journal of Product Innovation Management 25(5), 436-456. http://dx.doi.org/10.1111/j.1540-5885.2008.00313.x

Vermeulen, P., 2005, 'Uncovering barriers to complex incremental product innovation in small and medium-sized financial services firms', Journal of Small Business Management 43(4), 432-452. http://dx.doi.org/10.1111/j.1540-627X.2005.00146.X

Wang, M.\& Fischbeck, P., 2008, 'Evaluating lotteries, risks, and risk-mitigation programs', Journal of Risk Research 11(6), 775-795. http://dx.doi. org/10.1080/13669870801967259

Weber, E., Ames, D. \& Blais, A-R., 2005, 'How do I choose thee? Let me count the ways: A textual analysis of similarities and differences in modes of decision ways: A textual analysis of similarities and differences in modes of decision 87-118. http://dx.doi.org/10.1111/j.1740-8784.2004.00005.x

Weber, E., Blais, A. \& Betz, N., 2002, ‘A domain-specific risk-attitude scale: Measuring risk perceptions and risk behaviours', Journal of Behavioral Decision Making 15, 263-290. http://dx.doi.org/10.1002/bdm.414

Weber, E. \& Hsee, C., 2000, 'Culture and individual judgment and decision-making, Journal of Applied Psychology 49, 32-61.

Weber, E. \& Milliman, R., 1997, 'Perceived risk attitudes: Relating risk perception to risky choice', Management Science 43, 122-143. http://dx.doi.org/10.1287/ mnsc.43.2.123

Wiklund, J., Davidsson, P., Audretsch, D. \& Karlsson, C., 2011, 'The Future of entrepreneurship research', Entrepreneurship Theory and Practice 35(1), 1-9. http://dx.doi.org/10.1111/j.1540-6520.2010.00420.x

Wiseman, R. \& Gomez-Mejia, L., 1998, 'A behavioural agency model of managerial risk taking', Academy of Management Review 23(1), 133-153.

Xu, H. \& Ruef, M., 2004, 'The myth of the risk-tolerant entrepreneur', Strategic Organization 2(4), 331-355. http://dx.doi.org/10.1177/1476127004047617

Zahra, S., 2007, 'Contextualizing theory building in entrepreneurship research', Journal of Business Venturing 22(3), 443-452.

Zahra, S., Ireland, R., Gutierrez, I. \& Hitt, M., 2000, 'Privatization and entrepreneurial transformation: Emerging issues and a future research agenda', Academy of Management Review 25, 509-524.

Zahra, S., Sapienza, H. \& Davidsson, P., 2006, 'Entrepreneurship and dynamic capabilities: A review, model and research agenda', Journal of Management Studies 43, 917-955. http://dx.doi.org/10.1111/j.1467-6486.2006.00616.x 